\title{
Analysis of the effect of sludge loading on phosphorus removal in SBR wastewater treatment system
}

\author{
Tian Xiaoyan ${ }^{1, a}$, Lu Ying ${ }^{1, b}$ \\ ${ }^{1}$ School of Municipal and Environmental Engineering , The University of Jilin architecture \\ Changchun,130018, China \\ atxy1317@163.com, ${ }^{\mathrm{b}} 938223457 @ q q . c o m$
}

\begin{abstract}
Keywords: Biological removal phosphorus; Reaction temperature; COD load of sludge; Anaerobic release phosphorus; Aeration rate
\end{abstract}

Abstract. Based on SBR we discussed on biological removal phosphorus system. In the reaction temperature at $15^{\circ} \mathrm{C}$ and $25^{\circ} \mathrm{C}$ under the conditions of influent COD/TP ratio and COD load of sludge. Total phosphorus concentration of influent was be constant for $10 \pm 0.5 \mathrm{mg} / \mathrm{L}$, compared to anaerobic paragraph at the end of the water and TP concentration. The results showed that: (1) Under both temperature conditions the effluent $\mathrm{TP}$ concentration is reducing with the influent $\mathrm{COD} / \mathrm{TP}$ ratio increase, especially when the influent COD/TP ratio is more than or equal to forty, the effluent TP concentration is below $1 \mathrm{mg} / \mathrm{L}$. (2) Two temperatures with the COD load of sludge was risen from the effect to reduce the concentration of TP, when the sludge COD load $\geq 0.46 \mathrm{mgCOD} / \mathrm{mgMLSS} \cdot \mathrm{d}$, the effluent TP concentration was lower than $1 \mathrm{mg} / \mathrm{L}$; (3) In reaction temperature of $25^{\circ} \mathrm{C}$ and $15^{\circ} \mathrm{C}$, the amount of anaerobic releasing paragraph and COD load of sludge are very good correlation, linear relationship between the two were: $\mathrm{y}=0.72+71.91 \times\left(25^{\circ} \mathrm{C}\right), \mathrm{y}=2.81+73.33 \times\left(15^{\circ} \mathrm{C}\right)$; (4) In the COD load of sludge under the same conditions, the removal rate in $15^{\circ} \mathrm{C}$ is higher $5 \%$ than the one in $25^{\circ} \mathrm{C}$; (5)The effluent of aeration rate on the phosphorus removal efficiency of SBR system was investigated, which showed that the aeration rate was an important factor affecting the activity of poly. Increasing the aeration rate will greatly increase the phosphorus uptake efficiency of the phosphorus accumulating bacteria, and increase the phosphorus removal efficiency.

\section{Introduction}

New craft of phosphorus (P) removal has been developed duo to release/attracts the An/O process 、 PhoStrip process 、 VIP process $\mathrm{A}^{2} \mathrm{O}$ process 、 Bardenpho process 、 UCT process and SBR process etc. However, its effect usually limited to many factor which regardless of what form processing craft by $\mathrm{P}$ removal principle, including reaction temperature, $\mathrm{DO}$ in the aerobic/ anaerobic paragraph, sludge age, NO3 $-\mathrm{N}$ concentration in the anaerobic paragraph, Nutrition ratio of influent with reaction temperature and COD load of sludge being the main biological removal phosphorus factor. Hence this paper dedicates to a detailed discussion based on An/OSBR craft to it.

\section{Materials and methods}

\section{A Experimental}

All of the laboratory scale models used in this work (Fig.1) were made of plexglass. The size of the An/OSBR was: $40 \mathrm{~cm}$ height, $10 \mathrm{~cm}$ diameter and the base bagger is the frustum shape. The useful volume of the reactor was divided into four discrete compartments of equal height $(10 \mathrm{~cm})$.Every compartment was equipped with ports for the sampling of liquid, as well as it was outlet of wastewater. The reactor was installed pipe with sludge. the air supply was the porous stone as the pore waterfall propose, such as Phosphate Accumulating Organisms) had phosphorus principle of PAOs (Poly by air compressor with drum wind aeration way. Reactor is fixed the mixer, and its user maintain spate mix evenly when non-aeration condition or aeration quantity is less.

All experiment were done in a temperature control changer with a temperature of $25^{\circ} \mathrm{C}$. And it were monitored in unceasingly a variation of $\mathrm{DO}, \mathrm{ORP}$ and the $\mathrm{pH}$ value in the reaction process with 
appropriate transducer. Sludge age $(\theta \mathrm{c})$ of process are control about 10 days. Until use, the MLSS were kept at $2500 \mathrm{mg} / \mathrm{l}$.

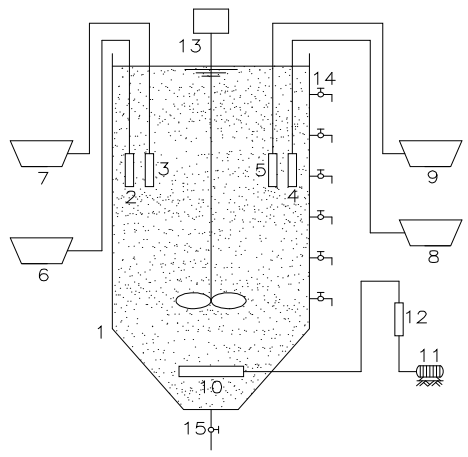

Fig.1.The configuration of An/OSBR process

1-Reactor; 2- $\mathrm{pH}$ transducer; 3-DO transducer;4-ORP transducer;5-temperature transducer; 6- $\mathrm{pH}$ cryoscope; 7-DO cryoscope; 8-ORP cryoscope; 9-temperature controller; 10-Aeration head; 11-air compressor; 12-flow meter; 13-mixing; 14-sampling: 15 - outlet of sludge

\section{B Wastewater and sludge}

The influent fed into the full-scale reactor was the municipal wastewater generated intermixture of beer wastewater and protein peptone. In addition, inorganic nutrients also are essential, $\mathrm{NaHCO}_{3}$ for alkalinity of solution, and $\mathrm{NH}_{4} \mathrm{Cl}$ for density of ammonia nitrogen, and $\mathrm{KH}_{2} \mathrm{PO}_{4}$ for density of water phosphate, and inorganic elements such as calcium, magnesium, may also be required for PAOs growth. Minor nutrients is necessary to growth of active sludge microorganism. Ingredient and figures of simulation wastewater are identified in Table 1.

Experimental vaccination sludge come from returned sludge of secondary deposit chamber of MUCT process in experiment. It had been start by simulation municipal wastewater at 2007.10. After ten weeks later ,it is stable for removal phosphorus effect in system and then sampling and determination.

Table1 Components of simulational wastewater and feature of water quality

\begin{tabular}{|c|c|c|c|c|c|}
\hline \multicolumn{2}{|c|}{$\begin{array}{l}\text { Components of simulational } \\
\text { wastewater }\end{array}$} & \multicolumn{2}{|c|}{ Minor factor } & \multicolumn{2}{|c|}{ Quota of water quality } \\
\hline $\begin{array}{l}\text { Medical } \\
\text { preparation }\end{array}$ & $\begin{array}{c}\text { Throws the } \\
\text { increment } / \mathrm{g} \cdot \mathrm{L}^{-1}\end{array}$ & Compose & Concentration $/ \mathrm{g} \cdot \mathrm{L}^{-1}$ & Iitem & $\begin{array}{c}\text { Concentration } / \mathrm{mg} \\
\cdot \mathrm{L}^{-1}\end{array}$ \\
\hline $\begin{array}{c}\text { Beer } \\
\text { wastewater }\end{array}$ & $1.5 \sim 3.5 \mathrm{~mL} / \mathrm{L}$ & $\mathrm{FeCl}_{3}$ & 0.9 & COD & $200 \sim 500$ \\
\hline Peptone & 0.1 & $\mathrm{H}_{3} \mathrm{BO}_{4}$ & 0.15 & BOD & $118 \sim 315$ \\
\hline $\mathrm{NH}_{4} \mathrm{Cl}$ & 0.1 & $\mathrm{CoCl}_{2} \cdot 7 \mathrm{H}_{2} \mathrm{O}$ & 0.15 & $\mathrm{TN}$ & $23.5 \pm 1$ \\
\hline $\mathrm{KH}_{2} \mathrm{PO}_{4}$ & 0.044 & $\mathrm{CuSO}_{4} \cdot 5 \mathrm{H}_{2} \mathrm{O}$ & 0.03 & $\mathrm{NH}^{4+}-\mathrm{N}$ & $21.1 \pm 0.8$ \\
\hline $\mathrm{NaHCO}_{3}$ & $0.16 \sim 0.8$ & $\mathrm{KI}$ & 0.18 & $\mathrm{NO}^{3-}-\mathrm{N}$ & $<1$ \\
\hline $\mathrm{CaCl}_{2}$ & 0.01 & $\mathrm{MnCl}_{2} \cdot 4 \mathrm{H}_{2} \mathrm{O}$ & 0.06 & $\mathrm{NO}^{2-}-\mathrm{N}$ & $<1$ \\
\hline $\mathrm{MgSO}_{4}$ & 0.05 & $\mathrm{Na}_{2} \mathrm{Mo} \cdot 2 \mathrm{H}_{2} \mathrm{O}$ & 0.06 & $\mathrm{TP}$ & $10.0 \pm 0.5$ \\
\hline $\begin{array}{c}\text { Minor factor } \\
\text { liquid }\end{array}$ & $0.6 \mathrm{~mL} / \mathrm{L}$ & $\mathrm{ZnSO}_{4} \cdot 7 \mathrm{H}_{2} \mathrm{O}$ & 0.12 & $\mathrm{pH}$ & $6.9 \sim 7.1$ \\
\hline
\end{tabular}

\section{Examination project and method}

Supernatant of water sample was determination by centrifugal; COD was determination by fast detector of 5B-1; TP was determination by molybdenum-antimony anti-spectrophotometric; $\mathrm{NH}^{4+}-\mathrm{N}$ adopt Nessler 's reagent spectrophotometry; $\mathrm{NO}^{3-}-\mathrm{N}$ adopt thymol spectrophotometry; $\mathrm{NO}^{2-}-\mathrm{N}$ adopt $\mathrm{N}$ - (1-naphthyl) -ethylenediamine spectrophotometric method; MLSS was determination by filter paper weight; SVI was determination by standard method (SV30/MLSS). 


\section{Discussion}

Fig2 shows that the variation of effluent TP concentration and TP recovery rate under different $\mathrm{COD} / \mathrm{TP}$ ratio conditions at the reaction temperature $25^{\circ} \mathrm{C}$ and $15^{\circ} \mathrm{C}$. The content of anaerobic P-release was calculated with balancing of materials. When the influent COD/TP ratio is equal to or greater than forty, the effluent TP concentration is below $1 \mathrm{mg} / \mathrm{L}$ and the TP recovery rate is more than $90 \%$, that is to say the SBR process has high phosphorus removal efficiency. When the influent $\mathrm{COD} / \mathrm{TP}$ ratio is less than or equal to 35 , the effluent TP concentrations are high both at reaction temperature $25^{\circ} \mathrm{C}$ and $15^{\circ} \mathrm{C}$, so the TP recovery rate are lower than $84.7 \%$ and $88.6 \%$.

TP (total phosphorus) Concentration and elimination rate of TP was indicated in Fig. 3 in different sludge load in reaction temperature $25^{\circ} \mathrm{C}$ and $15^{\circ} \mathrm{C}$. And the amount of anaerobic releasing paragraph which gained by the mass balance in the anaerobic was indicated in Fig.3 in different sludge load in reaction temperature $25^{\circ} \mathrm{C}$ and $15^{\circ} \mathrm{C}$. It is obvious that $\mathrm{TP}$ concentration lower than $1 \mathrm{mg} / \mathrm{L}$ and elimination rate above $90 \%$, SBR process may acquire ideal phosphorus removal effect, under the condition of COD load of sludge $\geq 0.46 \mathrm{mgCOD} / \mathrm{mgMLSS} \cdot \mathrm{d}$.And when COD load of sludge $\leq 0.40 \mathrm{mgCOD} / \mathrm{mgMLSS} \cdot \mathrm{d}$ and reaction temperature is $25^{\circ} \mathrm{C}$ and $15^{\circ} \mathrm{C}$, the throughput of total phosphorus of effluent is high and elimination rate is lower than $84.7 \%$ 、88.6\% separately.
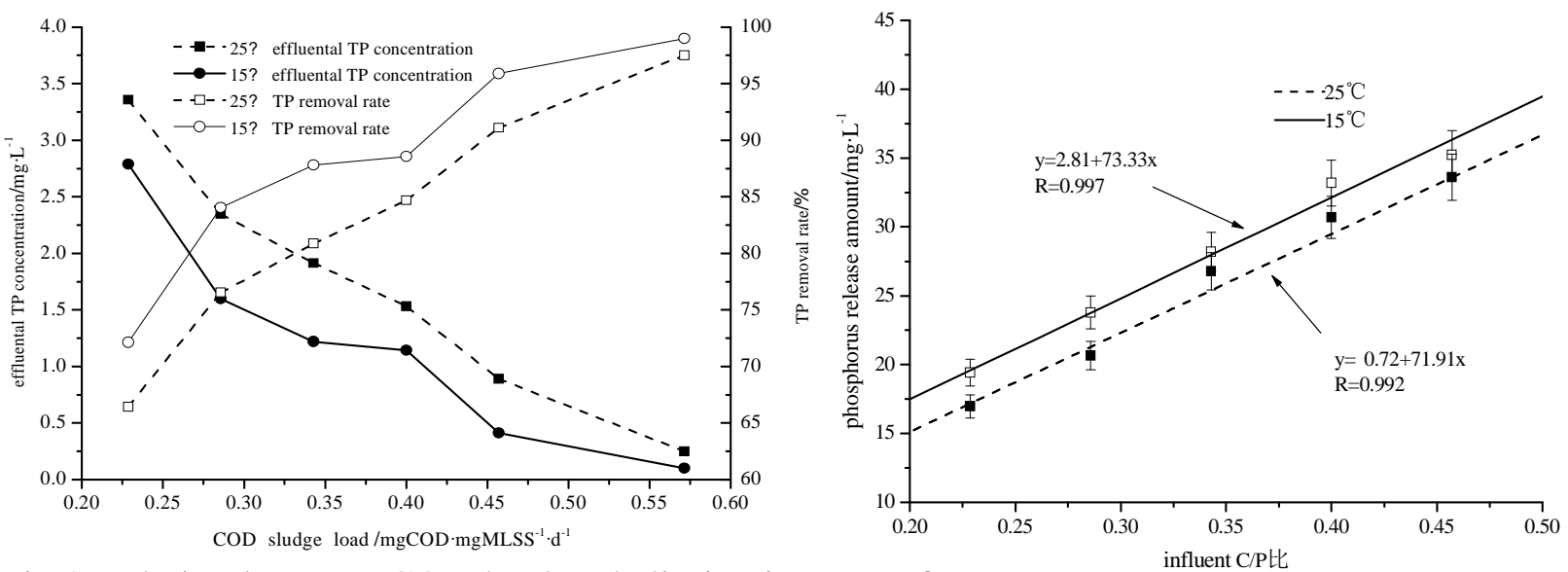

Fig.2 Relation between COD load and elimination rate of TP Fig.3 Relations both COD load

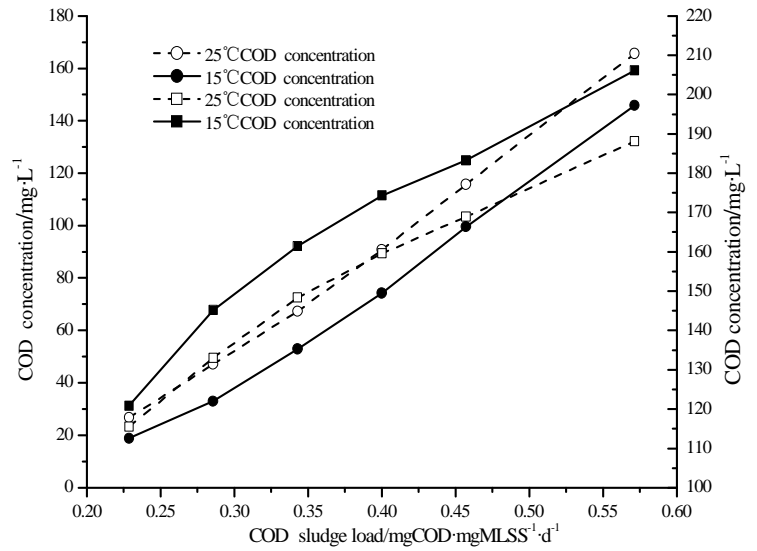

Fig.4 Express relation between concentration of COD in the anaerobic segment

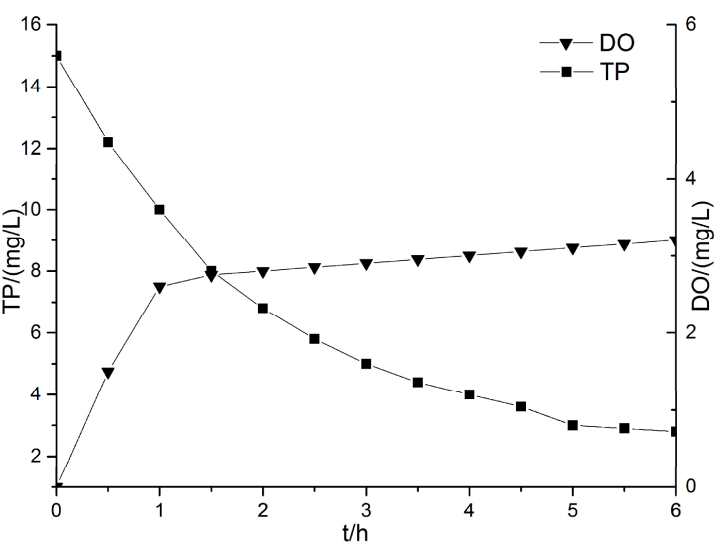

Fig.5 The relation of TP and DO changes over the time

It is obvious in Fig.4 that throughput of phosphorus in anaerobic segment was increased when COD sludge load rise. According to basic principle we may infer that consumption of COD in anaerobic segment was absorbed by PAOs and then stored interior by PHB for using the PAOs excessive attracts the phosphorus in later aerobic segment. After data fitting we find out that there are a good relevance between throughput of phosphorus and COD sludge load when reaction temperature of $25^{\circ} \mathrm{C}$ and $15^{\circ} \mathrm{C}$. And two group of data tally with the following function relationship:

$\mathrm{y}=0.72+71.91 \mathrm{x}$. 
$\mathrm{y}=2.81+73.33 \mathrm{x}$.

And X represent COD sludge load, Y represent throughput of phosphorus.

It can be seen from Fig. 4 that with the increase of the aeration rate, the oxygen transfer rate increases and the DO of the SBR system increases. At the same time, the rate of uptake of phosphorus by anaerobic bacteria also increased accordingly. It can be seen from the figure, DO close to $4 \mathrm{mg} / \mathrm{L}$, phosphorus removal effect is good and stable.

Fig. 5 express relation between concentration of COD in the anaerobic segment and consumption of COD. When the biomass almost maintains at $2500 \mathrm{mg} / \mathrm{L}$, and has the same numbers of PAOs, we may find out that consumption of COD in the anaerobic section was increased along with increasing of COD load of sludge It indicate that storage capacity of PHB in the anaerobic segment no only decided by number of PAOs but also decided by concentration of COD, and more COD lead to advantageous to the PHB storage, larger reserves. That is to say throughput of PHB under the condition of anaerobic incomplete depend on energy which providing by hydrolysis high energy phosphoric acid key.

We may draw the conclusion from Fig.3、Fig.4 and Fig.5 that TP elimination effect at $15^{\circ} \mathrm{C}$ is higher about $5 \%$ than temperature is $25^{\circ} \mathrm{C}$, when COD load of sludge is the same. When COD load of sludge was $0.46 \mathrm{mgCOD} / \mathrm{mgMLSS} \cdot \mathrm{d}$ and reaction temperature was $25^{\circ} \mathrm{C}$, now concentration of $\mathrm{TP}$ was $0.89 \mathrm{mg} / \mathrm{L}$,remove rate of TP was $91.1 \%$, throughput of phosphorus in anaerobic segment was $33.61 \mathrm{mg} / \mathrm{L}$, concentration of COD in the later anaerobic segment was $115.76 \mathrm{mg} / \mathrm{L}$ and consumption of COD was $168.94 \mathrm{mg} / \mathrm{L}$; Simultaneously, when reaction temperature was $15^{\circ} \mathrm{C}$, and then concentration of TP was $0.41 \mathrm{mg} / \mathrm{L}$, remove rate of TP was $95.88 \%$, throughput of phosphorus in anaerobic segment was $35.23 \mathrm{mg} / \mathrm{L}$, concentration of COD in the later anaerobic section was $99.56 \mathrm{mg} / \mathrm{L}$ and consumption of COD was $183.31 \mathrm{mg} / \mathrm{L}$. Its reason is as follows: (1) The accumulation of content in vivo of certain microorganism depend on temperature deeply, a companying with rising in temperature and then throughput of PHB was reduced. (2) Minor of PAOs is addicted to the warm fungus and major of PAOs is addicted to the cool fungus, therefore, they holds the superiority when temperature was $20^{\circ} \mathrm{C}$ or slightly low temperature condition. According to this experiment result we may know the high temperature will affect to eliminate the phosphorus effect in the system. In order to overcome this question, it is necessary that the system carries on temperature abate processing or the guarantee system carbon source is sufficient.

The variation of e COD load of sludge has the slight effect upon remove rate of COD during experiment period, in system remove rate of COD was about $90 \%$, and $65 \% \sim 85 \%$ COD in the anaerobic segment was consumption.

\section{Conclusions}

(1)When the influent COD/TP ratio is more than or equal to 40 , the effluent TP concentration is below $1 \mathrm{mg} / \mathrm{L}$ at $25^{\circ} \mathrm{C}$ and $15^{\circ} \mathrm{C}$ in $\mathrm{An} / \mathrm{OSBR}$ reactor, the phosphorus recovery rate is more than $90 \%$, so the An/OSBR has high phosphorus removal efficiency. When the influent COD/TP ratio is less than or equal to 35, because carbon is shortage, the TP recovery rate is low under both conditions, and the effluent TP concentration is more than $1 \mathrm{mg} / \mathrm{L}$.

(2)When COD load of sludge $\geq 0.46 \mathrm{mgCOD} / \mathrm{mgMLSS} \cdot \mathrm{d}$, regardless of reaction temperature was $25^{\circ} \mathrm{C}$ or $15^{\circ} \mathrm{C}$, concentration of TP in the effluent all lower than $1 \mathrm{mg} / \mathrm{L}$, remove rate was above $90 \%$, SBR process may obtain ideal effect upon remove rate of phosphorus; When COD load of sludge $\leq 0.40 \mathrm{mgCOD} / \mathrm{mgMLSS} \cdot \mathrm{d}$, because lacks the carbon source lead to remove rate of COD was low, and concentration of TP was higher than $1 \mathrm{mg} / \mathrm{L}$.

(3)Throughput of COD in the anaerobic segment and COD load of sludge existence good relevance, and they cater for linear relationship, respectively is $\mathrm{y}=0.72+71.91 \mathrm{x}\left(25^{\circ} \mathrm{C}\right)$, $\mathrm{y}=2.81+73.33 \mathrm{x}\left(15^{\circ} \mathrm{C}\right)$. 
(4)When there is a same COD load of sludge, remove rate of COD at $15^{\circ} \mathrm{C}$ was higher than $25^{\circ} \mathrm{C}$ above 5\%,moreover,throughput of phosphorus and consumption of COD in the anaerobic section in systern also higher .

(5)The effect of aeration rate on the phosphorus removal efficiency of SBR system was investigated, which showed that the aeration rate was an important factor affecting the activity of poly. Increasing the aeration rate will greatly increase the phosphorus uptake efficiency of the phosphorus accumulating bacteria, and increase the phosphorus removal efficiency.

\section{References}

[1] Chengjiang Li, Xingcan Zheng. Technology of eliminating the phosphorus denitrogenation in wastewater Beijing: China Building industry Publishing express, 1992 . 244.

[2] Tianmin Jiang, Haiguang Yang, Shailin Chen. The sewage ingredient's change eliminates the phosphorus effect to the biology the influence. Environmental protection, 2003, (7) ; 24 27.

[3] Jie Li, Biyong Xiong, Jie Zhang. The anaerobic - good oxygen biology eliminates the phosphorus influencing factor the control. Ecological environment, $2004,13(4) ; 506 \sim 507,511$.

[4] Qinya Liu, Yejian Zhang. In putty age application related question discussion Prevention and control of pollution technology, $2003,16(2) ; 13 \sim 16$.

[5] Huailan Zhu, Jialuo Shi, Yatong Xu. SBR except phosphorus system's in product phosphobacteria. Shanghai environmental science. $1994,13(4): 16 \sim 18$.

[6] Shuyuan Tian, Jingfeng Wang, Rui Yang, Teizhu Lang, Xiuwen Yang. Anaerobic under PHB and gathers the phosphate and the biochemistry mechanism research. Water draining water in China.1999,15(3): 20-21.

[7] Larose A., et.al. Respirometric control of the anaerobic period duration of an SBR Bio-P process. Wat.Sci. Tech. 2003, 36(5): 293 300.

[8] Fuhs GW and Chen M. Microbiological Basis of Phosphate Removal in the Activated Sludge Processf or the Treatment of Wastewater. Microbial, Ecol.1975, 2( 2): 119 138 .

[9] BuchanL. Possible Biological Mechanism of Phosphorus Removal.Wat.Sci.Tech.1983,15(34): 87-103.

[10] T. George, F. L. Burton, H. D. Stensel. Wastewater Engineering: Treatment Disposal and Reuse. Fourth edition. Metcalf and Eddy, Inc. McGraw-Hil, 2000: 287 290. 